\title{
OPTIMALISASI PELAYANAN DOKUMEN KEDATANGAN KAPAL ASING SAAT TERJADINYA COVID-19
}

\author{
Sulida Erliyana ${ }^{1 *}$, Evita Oktaviana ${ }^{2}$ \\ ${ }^{1 \& 2}$ Program Studi KPN - Politeknik Bumi Akpelni \\ Jl. Pawiyatan Luhur II/17 Bendan Duwur, Gajah Mungkur - Semarang \\ Email : erliyanasulida@yahoo.co.id
}

\begin{abstract}
Abstrak
Penulisan ini bertujuan untuk mengkaji dan menjelaskan tentang pelayanan keagenan dalam menangani kedatangan kapal asing saat terjadinya pandemi COVID-19. Metode pengumpulan data dilakukan dengan menggunakan pendekatan deskriptif kualitatif, yaitu menganalisa dokumen berupa kumpulan kata kata tertulis dari orang-orang yang melakukan kegiatan di lapangan yang telah diamati oleh peneliti. Selain itu, pengumpulan data juga dilakukan kepada obyek penelitian melalui metode observasi, metode wawancara dan metode kepustakaan. Dari hasil pembahasan, diperoleh bahwa pelayanan keagenan dalam menangani kedatangan kapal asing saat terjadi pandemi COVID-19 dilakukan dengan cara memberikan solusi terhadap permasalahan yang ada, antara lain menyelesaikan clearance in dengan cepat, menggunakan masker, sarung tangan, handsinitizer, dan mematuhi protkcol kesehatan yang berlaku. Selain itu, hal yang paling penting adalah meningkatkan koordinasi dengan instansi yang terkait dalam hal kedatangan kapal, dan menyiapkan atau mengecek dokumen kapal dengan baik agar tidak ada kekurangan dokumen, dan demi kelancaran proses clearance in yang penanganannya berbeda ketika sebelum dan sesudah pandemi Covid 19. Dari hal tersebut dapat disimpulkan bahwa pelayanan keagenan masih belum dioptimalkan sehingga dibutuhkan evaluasi terhadap beberapa masalah agar terjadi suatu peningkatan dalam pelayanannya serta memfasilitasi yang masih di nilai kurang agar menjadi perusahaan keagenan yang berperan secara baik.
\end{abstract}

Kata kunci : dokumen, keagenan, dan pelayanan

\section{PENDAHULUAN}

Kebutuhan akan jasa angkutan laut semakin lama semakin meningkat, baik jumlahnya maupun macamnya. Salah satu komponen dari sistem angkutan laut adalah pelabuhan, dimana pelabuhan laut merupakan salah satu sub sistem transportasi laut yang mempunyai fungsi utama, yaitu sebagai tempat yang aman untuk berlabuh dan bertambatnya kapalkapal serta sebagai terminal transfer barang dan penumpang melalui angkutan darat dan angkutan laut. Dengan adanya penyebaran COVID-19 yang sedang terjadi, kegiatan di pelabuhan tetap berjalan. Saat transportasi manusia masih menggunakan kapal laut, pelayaran menjadi media penyebaran wabah antar negara dan antar benua. Jadi, dunia pelayaran tidaklah asing dengan wabah penyakit dan karantina. Sejak digantikan pesawat udara sebagai moda utama transportasi manusia (jarak jauh), resiko kapal laut sebagai media penularan relatif kecil. Dengan resiko yang sudah relatif kecil, pelayaran tetap beroperasi dengan prosedur keselamatan yang semakin baik.

Setiap kapal beroperasi mengikuti manajemen keselamatan. Awak kapalnya memiliki sertifikat, penanda mereka memiliki kualifikasi pengetahuan, keahlian, dan pengalaman tertentu. Bekerja dengan manajemen keselamatan artinya terbiasa menghadapi keadaan darurat. Tidak sulit bagi awak kapal untuk melaksanakan rekomendasi WHO, IMO, dan IMH. Termasuk mengikuti petunjuk dari otoritas pelabuhan dalam upaya pencegahan dan penanggulangan penyebaran COVID-19 di pelabuhan. Agen pelayaran kapal asing harus melengkapi dokumen perizinan kedatangan kapal tersebut melalui sistem online yaitu Inaportnet dimana agen pelayaran mengajukan permohonan kedatangan kapal termasuk asal pelabuhan sebelumnya, identitas kapal dan juga muatannya serta 
status awak kapalnya sebelum masuk ke Indonesia.

Dengan adanya COVID-19 yang telah tersebar diberbagai negara mulai tahun 2019, juga berdampak terhadap datangnya kapal asing, karena dengan adanya COVID-19 tersebut setiap kapal asing yang masuk ke pelabuhan Indonesia harus melalui proses pemeriksaan sesuai dengan Standar dan Prosedur (SOP) kedatangan kapal asing dan juga awak kapalnya telah melalui pemeriksaan kesehatan sesuai SOP Kantor Kesehatan Pelabuhan (KKP) untuk mengantisipasi penyebaran COVID-19.

Agen perusahaan pelayaran mempunyai peranan penting dalam kegiatan pelayaran, yang berpengaruh pada kelancaran perdagangan dan perekonomian khususnya ekspor Batu Bara, karena agen pelayaran yang sangat besar dalam kegiatan/ keperluan kapal selama di pelabuhan.

\section{Rumusan Masalah}

1. Proses penanganan pelayanan kedatangan kapal asing

2. Pengaruh terjadinya COVID-19 terhadap penanganan kedatangan kapal asing

3. Dokumen - dokumen yang diperlukan untuk optimalisasi pelayanan kedatangan kapal asing.

\section{LANDASAN TEORI}

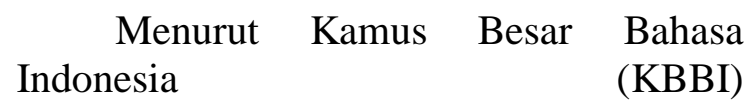

https://kbbi.kemdikbud.go.id/, pengertian memaksimumkan tujuan dari suatu perusahaan atau bentuk organisasi yang lain. Optimalisasi merupakan ukuran yang menyebabkan tercapainya tujuan. Penulis lebih memilih kata optimalisasi karena mempunyai kata dasar optimal sehingga pembaca dapat langsung mengetahui bahwa penyusun kata tersebut adalah optimal+isasi. Menurut KBBI arti kata optimal adalah terbaik, tertinggi, atau paling menguntungkan.
Pelayanan menurut Moenir (2016:27) adalah kegiatan yang dilakukan oleh seseorang atau sekelompok orang dengan landasan melalui sistem, prosedur, dan metode tertentu dalam rangka usaha memenuhi kepentingan orang lain sesuai dengan haknya. Dapat dikatakan bahwa pelayanan merupakan upaya pemenuhan kebutuhan oleh seseorang atau organisasi kepada orang atau organisasi lain sehingga pihak yang dilayani memperoleh kepuasan atas pelayanan yang diterima baik secara fisik maupun non-fisik. Sebagai proses, pelayanan berlangsung secara rutin dan berkesinambungan, meliputi seluruh kehidupan orang dalam masyarakat.

Menurut UU Nomor 17 Tahun 2008 pasal (1) ayat 39 tentang Pelayaran pengertian kapal asing adalah kapal yang berbendera selain Indonesia dan tidak dicatat dalam daftar kapal Indonesia. Kapal asing dilarang mengangkut penumpang dan atau barang antarpulau atau antar pelabuhan di wilayah perairan pelabuhan. Pelaksana kegiatan angkutan laut asing yang melakukan kegiatan angkutan laut khusus ke pelabuhan Indonesia wajib menunjuk perusahaan angkutan laut nasional atau pelaksana kegiatan angkutan laut khusus sebagai agen umum. Perusahaan angkutan laut asing yang melakukan kegiatan angkutan laut ke atau dari pelabuhan Indonesia yang terbuka untuk perdagangan luar negeri secara berkesinambungan dapat menunjuk perwakilannya di Indonesia.

$$
\text { Menurut Purwanto, }
$$

https://www.jbiomedkes.org/, dalam kaitannya dengan kedatangan kapal, saat ini sedang mewabah virus yang sudah tersebar di Negara Indonesia yaitu COVID-19 yang menyebabkan proses penanganan kedatangan kapal sedikit terhambat. COVID-19 merupakan kelompok virus terbesar dalam ordo Nidoviraless. Wuhan, ibu kota provinsi Hubei di China tengah, pada awal Desember 2019 seorang pasien didiagnosis menderita pneumonia yang tidak biasa. Pada 31 Desember 2019, kantor regional 
Organisasi Kesehatan Dunia (WHO) di Beijing telah menerima pemberitahuan tentang sekelompok pasien dengan pneumonia yang tidak diketahui penyebabnya dari kota yang sama. Para peneliti di Institute of Virology di Wuhan telah melakukan analisis metagenomics untuk mengidentifikasi COVID-19 baru sebagai etiologi potensial. Mereka menyebutnya novel coronavirus 2019 (nCoV-2019). Selanjutnya, Pusat Pengendalian dan Pencegahan Penyakit AS (CDC) menyebut COVID-19 sebagai 2019 novel coronavirus (2019 nCoV) dan sekarang penyakitnya populer dengan istilah coronavirus disease-19 (COVID19).

\section{METODE}

Metode Pengumpulan data yang dilakukan oleh peneliti dalam kajian ini dengan melakukan 3 jenis pendekatan, yaitu:

1. Metode Observasi atau Pengamatan

2. Metode Interview

3. Metode Studi Pustaka

\section{PEMBAHASAN}

\section{Proses Penanganan Pelayanan Kedatangan Kapal Asing saat terjadi COVID-19}

Persiapan Sumber Daya Manusia yaitu dari dalam perusahaan disiapkan petugas bagian operasional, dari luar perusahaan yang perlu dihubungi yaitu petugas PT Pelindo, PT Perusahaan Bongkar Muat (PBM), Kesyahbandaraan, Imigrasi, dan Kantor Kesehatan Pelabuhan. Persiapan Perlengkapan/Peralatan untuk bagian operasional peralatan yang disiapkan yaitu handy talkie, stempel dari perusahaan, tanda pengenal dari perusahaan identity card, safety jacket, helm, tas, lampu rotetor, lampu senter, dan sepatu safety. Karena sedang terjadi COVID-19 maka juga diperlukan alat-alat kesehatan seperti masker, sarung tangan dan handsinitizer. Untuk bagian kantor yang disiapkan adalah alat tulis, mesin foto copy, faksimili, pesawat telepon, almari arsip, dll. Tempat
Kegiatan Operasional Keagenan Kapal. Tempat-tempat untuk melaksanakan kegiatan adalah kantor perusahaan, kantor kesyahbandaran, kantor imigrasi, kantor karantina, dermaga, dan docking kapal jika kapal perlu masuk docking. Persiapan dokumen untuk Syahbandar, dokumen untuk Imigrasi, dan dokumen untuk Kantor Karantina Pelabuhan.

\section{Pelaksanaan Pelayanan Kapal di Pelabuhan meliputi :}

Penerimaan Informasi dari principal, Pemberitahuan Kedatangan Kapal, Komunikasi dengan Nakhoda, Pemberitahuan Penunjukan Kapal Asing, Penurunan bendera isyarat karantina, Karena terjadi pandemi COVID-19 maka pihak karantina dan imigrasi untuk melakukan pemeriksaan harus ke tengah sebelum kapal di pandu, setelah dilakukan pemeriksaan awak kapal barulah kapal diperbolehkan masuk ke pelabuhan dengan syarat bebas karantina. Untuk mencegah penularan COVID-19 agen dan juga pihak karantina beserta imigrasi juga diwajibkan menggunakan masker, cuci tangan menggunakan sabun, memakai handsinitizer, jaga jarak 1-2 meter, Permohonan Labuh, Pandu, dan Tambat Kapal, ketika kapal sudah dekat kapal berkomunikasi dengan agen dan agen akan mengajukan permohonan labuh kepada pandu, tunda kapal dan tambat kapal di dermaga. Selanjutnya agen pelayaran hanya tinggal menunggu proses pergerakan dari kolam Bandar menuju Dermaga, penyandaran dan penambatan kapal di dermaga, Pengambilan dokumen kapal dan awak kapal, Dokumen-dokumen tersebut kemudian di buat memorandum, pemenuhan keperluan awak kapal, penyerahan dokumen kapal ke Kantor Syahbandar, Imigrasi, dan Karantina, penerbitan dokumen kapal ke Kantor Syahbandar, Imigrasi, dan Karantina, pembayaran biaya penerbitan dokumen. 


\section{Kelayakan Kapal}

Dalam melakukan kegiatan keagenan, kita sebagai agen kapal harus mengerti apakah kapal yang kita ageni sudah laik laut atau belum. Apabila terbukti kapal belum laik laut, maka dari kewenangan KSOP (Syahbandar) akan memberikan denda bagi perusahaan keagenan tersebut. Adapun cara untuk melihat kelaik lautan kapal, kita bisa memeriksa kelengkapan dokumen-dokumen yang ada di kapal.

\section{Disbursement Kapal}

Untuk menjadi seorang agen kapal kita dituntut untuk mampu memberikan pelayanan jasa terbaik terhadap kapal yang kita ageni, salah satunya dengan cara memberikan pelayanan Disbursement kapal.

\section{Penanganan Kedatangan Kapal Asing Saat Terjadinya COVID-19}

Kapal asing yang masuk ke pelabuhan Indonesia harus melalui proses pemeriksaan sesuai dengan Standar Operasional Prosedur (SOP) kedatangan kapal asing dan juga awak kapalnya telah melalui pemeriksaan kesehatan sesuai dengan SOP Kantor Kesehatan Pelabuhan (KKP) untuk mengantisipasi penyebaran COVID-19.

Kapal-kapal tersebut tidak langsung begitu saja masuk ke pelabuhan tetapi melakukan prosedur kedatangan kapal asing dan harus labuh jangkar terlebih dahulu untuk dilakukan pemeriksaan kesehatan. Pihak agen bersama petugas KKP akan checking crew saat masih di area laut, setelah semuanya dianggap aman, barulah kapal datang.

Kapal asing melakukan lego jangkar diarea yang telah ditentukan dan jika hasil pemeriksaan seluruh awak kapal dinyatakan sehat maka kapal boleh masuk di pelabuhan yang sudah memenuhi standar ISPS Code. Namun, jika ada yang terindikasi COVID19 maka harus disiapkan langkah evakuasi dan dibawa ke rumah sakit rujukan di setiap provinsi.

Pengisian formulir Kartu Kewaspadaan Kesehatan Kementerian Kesehatan
Republik Indonesia yang isinya mengenai identitas masing-masing awak kapal, keluhan gejala sakit, dan suhu tubuh yang sudah dilakukan pengecekan oleh pihak karantina saat melakukan pemeriksaan. Pengisian formulir tersebut bertujuan untuk mengetahui apakah ada awak kapal yang terindikasi COVID-19 atau tidak, formulir tersebut nantinya akan diserahkan oleh KKP dan masing-masing awak kapal, yang kemudian formulir tersebut dilampirkan bersama crew list untuk penerbitan PHQC ( Port Health Quarantine Clearance ), kapal akan dilayani setelah berstatus bebas karantina.

Kapal-kapal asing yang tiba dipelabuhan juga melampirkan surat pernyataan bebas penyakit pneumonia yang ditandatangani oleh nakhoda atau maritime declaration health yang dilampirkan saat lapor tiba secara online dan disertai voyage memo (daftar 10 pelabuhan terakhir) yang disinggahi.

Pelayanan kedatangan kapal asing juga tidak seperti biasanya, harus mematuhi protocol kesehatan, yang mewajibkan menggunakan masker, handsinitizer, cuci tangan dengan sabun, PHBS (Perilaku Hidup Bersih Sehat), jaga jarak 1-2 meter, dan vaksinasi.

Dari pengaruh-pengaruh tersebut dapat disimpulkan bahwa ada perbedaan pelayanan kedatangan kapal asing sebelum COVID-19 dan sesudah COVID-19.

\section{Dokumen - dokumen kapal yang diperlukan dalam kedatangan kapal asing \\ Ship's Document}

Ship's Document atau disebut dokumen kapal yaitu dokumen yang harus dimiliki oleh setiap kapal dan harus berada di atas kapal, yang menyatakan tentang kelayak lautan kapal dalam berbagai fungsi atau bidang tertentu. Ship's Document yang diambil dari atas kapal oleh perusahaan pelayaran atau wakilnya secara umum digunakan untuk kepengurusan formalitas kepelabuhan seperti clearance kapal sebelum memulai sampai selesai dan siap 
berangkat ke pelabuhan tujuan berikutnya. Ship's Document dibagi menjadi dua yaitu Returnable Ship Document dan Non Returnable Ship Document.

\section{a. Returnable Ship Document}

Certificate of Registry, International Tonnage Certificate, Cargo Ship Safety Equipment Certificate, Cargo Ship Safety Radio Certificate, Safety Management Certificate, Document of Compliance, International Ship Security Certificate, International Oil Pollution Prevention Certificate (IOPP), Classification Certificate, Minimum Safe Manning Certificate, Inflatable Liferaft Certificate, CO2 Certificate, Fire Extinguisher Certificate, Port State Control Document, International Load Line Certificate, Port Clearance, Indonesia Health Book, Ship Security Officer Certificate, Continous Synopsis Record, Continous Synopsis Record., Medical Chest atau Medical Certificate, Crew List, Ship's Sanitation Exemption Certificate, Bulk Carrier Code I BC Code, Pasport

\section{b. Non Returnable Ship Document}

Crew Effect Declaration, Medicine

List, $\quad$ Narcotic List, Ship's Stores Declaration, Nil List, Vaccination List, List Port of Call, Arrival Condition, Ship's Particular

Dokumen muatan terdiri dari Bill of Lading, Cargo Manifest, Notice of Readiness (NOR), Statement of Fact / Time Sheet dan Mate's Receipt.

\section{KESIMPULAN}

1. Secara umum proses kegiatan operasional pelayanan kedatangan kapal asing saat terjadi COVID-19 kurang optimal karena prosesnya lebih membutuhkan waktu yang lama.

2. Terdapat pengaruh yang timbul saat terjadi pandemi COVID-19 terhadap optimalisasi pelayanan kedatangan kapal asing, yaitu pemeriksaan kesehatan yang harus dilakukan saat kapal masih berlabuh membuat pihak karantina harus menyita waktu yang cukup lama untuk datang ditempat kapal berlabuh. Crew kapal yang ada diatas kapal tidak diperbolehkan untuk turun kecuali ada urusan mendesak. Menggunakan masker, sarung tangan, dan handsinitizer membuat pelayanan kurang nyaman dan kurang efektif.

3. Dalam pelayanan kedatangan sebuah kapal tedapat 2 dokumen yaitu Ship's Document atau dokumen kapal dan dokumen muatan. Dokumen-dokumen ini biasanya akan dikirim melalui $e$ mail terlebih dahulu dengan judul prearrival docs yang akan diterima oleh pihak keagenan. Dokumen kapal sendiri terbagi menjadi 2 bagian lagi yaitu :

a. Returnable Ship Document

b. Non Returnable Ship Document

Sedangkan untuk dokumen muatan terdiri dari Bill of Lading, Cargo Manifest, Notice of Readiness (NOR), Statement of Fact / Time Sheet dan Mate's Receipt.

\section{DAFTAR PUSTAKA}

Hartatik, Indah Puji. 2014. Buku Pintar Membuat S.O.P (Standard Operating Procedure). Yogyakarta: Flashbooks.

H.A.S. Moenir. 2016. Manajemen Pelayanan Umum di Indonesia. Jakarta: Bumi Aksara

Menkumham. 2008. Undang-Undang Republik Indonesia tentang

Pelayaran (Nomor 17/2008). Jakarta: Menteri Hukum dan Hak Asasi Manusia Republik Indonesia.

MLE Purwanto. 2020. Virus Corona (2019. $n C o V)$ penyebab COVID-19.

Jurnal Biomedika dan Kesehatan, Vol.3 (1).

https://kbbi.kemdikbud.go.id/

Diakses tanggal 16 April 2020 jam 14.00 WIB 